Економічні науки: збірник наукових праць Луиького національного технічного університету. Серія "Регіональна економіка". Випуск 17 (67). Редкол.: відп. ред. к.е.н., професор І.В. Кривов’язюк. Луцьк: ІВВ Луцького НТУ, 2020. 348 с.

УДК 332.2

Полянська Т.О., асистент

Луцький національний технічний університет

Полянський С.В., к.г.н.

Волинський національний університет імені Лесі Українки Свередюк Н.В.

Волинський національний університет імені Лесі Українки

\title{
АНАЛІЗ СТРУКТУРИ ВИКОРИСТАННЯ ЗЕМЕЛЬНИХ РЕСУРСІВ ВОЛИНСЬКОЇ ОБЛАСТІ
}

У статті подано результати теоретичного та аналітичного дослідження різноманітності грунтового покриву, розвиток якого визначають такі чинники грунтоутворення, як рослинність, клімат, грунтоутворюючі та підстилаючі породи, рельєф, виробнича діяльність людини. Проаналізована динаміка структури землекористування адміністративно-територіальних одиниць Волинської області за останні десятиліття. Досліджено рівень ефективності використання сільськогосподарських угідь в районах на основі аналізу їх площ та рівня розораності, що дало змогу провести їх групування.

Запропоновано стратегічні пріоритети щодо підвищення ефективності використання земельних ресурсів. В основу огляду попередніх напрацювань покладено картографічний метод дослідження. Охарактеризовано результати досліджень проблеми раціонального використання та охорони земель у Волинській області.

Ключові слова: земельні ресурси, структура земельного фонду, розораність сільськогосподарських угідь, грунти, чинники грунтоутворення, рілля.

\section{Polianska T.O., Polianskiy S.V., Sveredyuk N.V.}

\section{ANALYSIS OF THE STRUCTURE OF THE USE OF LAND RESOURCES OF THE VOLYN REGION}

The article presents the results of theoretical and analytical study of the diversity of soil cover, the development of which is determined by factors of soil formation, such as vegetation, climate, soil-forming and underlying rocks, relief, human production activity.

Analyzed is the dynamics of the structure of land administration in the administrative and territorial units of the Volyn region for the remaining ten years. The basis for looking back ahead is laid on the cartographic method dosledzhennya. The results of the problem of the regional vikoristannya and the protection of land near the Volinsky region are characterized. 
Економічні науки: збірник наукових праць Луиького національного технічного університету. Серія "Регіональна економіка". Випуск 17 (67). Редкол.: відп. ред. к.е.н., професор І.В. Кривов’язюк. Луцьк: ІВВ Луцького НТУ, 2020. 348 с.

There is a clear analysis of the relevant indicators and the recommended parameters for environmental balancing of territorial organizations.

The analysis of territorial views of the naturalities and the government of Ukraine allowed the occurrence of offensive features: for the Polish part of the region, the most characteristic is the reduction of the open land and swampy land. A number of negative processes dominant $\epsilon$ eolov (on food and on overridden peat lands), a second wetland of small lands, overgrown with shagarniks and a rural roslinnistyu; districts with a high frequency of land in the structure of the land fund and low lisisty confined to the temporal lysostepovo part of the region. Here on schilovyh lands erosive processes are actively developing, physical and chemical degradation of the river, the river channels are small, the river channel is small, and the surface and the river water are dead.

Key words: land resources, the structure of the land fund, the variability of silver-lodged coal, Hrunti, officials of the ytrunutotvorennya, rillya.

\title{
Полянская Т.А., Полянский С.В., Свередюк Н.В. АНАЛИЗ СТРУКТУРЫ ИСПОЛЬЗОВАНИЯ ЗЕМЕЛЬНЫХ РЕСУРСОВ ВОЛЫНСКОЙ ОБЛАСТИ
}

\begin{abstract}
В статье представлены результаты теоретического и аналитического исследования разнообразия почвенного покрова, развитие которого определяют такие факторы почвообразования, как растительность, климат, почвообразовательные и подстилающие породы, рельеф, производственная деятельность человека. Проанализирована динамика структуры землепользования административно-территориальных единиц Волынской области за последние десятилетия. В основу обзора предыдущих наработок положено картографический метод исследования. Охарактеризованы результаты исследований проблемы рационального использования и охраны земель в Волынской области.
\end{abstract}

Ключевые слова: земельные ресурсы, структура земельного фонда, распашка сельскохозяйственных угодий, почвы, факторы почвообразования, пашня.

\section{Постановка проблеми у загальному вигляді та ії зв'язок з важливими науковими і практичними завданнями.} На сьогодні $є$ актуальною потреба у проведенні досліджень щодо використання, відтворення i збереження земельних ресурсів у Волинській області. Зміна економіко-екологічної ситуації, створення нових форм землекористування у Волинській області потребує досліджень, що дають змогу визначити напрямки i шляхи підвищення раціонального 
Економічні науки: збірник наукових праць Луиького національного технічного університету. Серія "Регіональна економіка". Випуск 17 (67). Редкол.: відп. ред. к.е.н., професор І.В. Кривов'язюк. Луиьк: ІВВ Луцького НТУ, 2020. 348 с.

землекористування. Стан розораності земель Волинської області $\epsilon$ високим i має тенденцію до зростання площ техногенно забруднених і малопродуктивних земель.

Метою даного дослідження є аналіз структури земельних угідь Волинської області для вирішення завдань ландшафтноекологічної оптимізації території. Для досягнення мети вирішувалися такі завдання: 1) вивчити історію досліджень стану земельних ресурсів та особливостей землекористування у Волинській області; 2) проаналізувати фізико-географічні умови та чинники грунтоутворення, як передумову формування сучасної структури земельного фонду; 3) визначити й проаналізувати рівень сільськогосподарської освоєності, розораності сільськогосподарських угідь, співвідношення природних і господарських угідь.

У роботі застосовано такі методи, як статистичний, аналізу та синтезу, порівняльно-географічний, картографічний, графічний тощо.

Аналіз останніх досліджень у яких започатковано вирішення проблеми. Детальний опис грунтів Волинської області та їх меліорація подано в монографіях [1; 3]. Вивчення структури земельного фонду та особливостей землекористування території певною мірою дає відповідь на питання про ступінь збереженості природної рослинності та стійкість геосистем до антропогенних навантажень, а результати таких досліджень $є$ суттєвим науковим підгрунтям для оптимізації ландшафтноекологічної організації території. Короткий огляд публікацій за темою. На сьогодні існує багато наукових праць вітчизняних та зарубіжних вчених, присвячених питанням раціонального використання земельного фонду. Детальний огляд історії досліджень проблем ландшафтноекологічної оптимізації території в цілому та аспектів використання й охорони сільськогосподарських земель відображено в статтях [1; 2; 3]. Стан земельних ресурсів та особливості землекористування у Волинській області досліджували Стрішенець О.М., Павловська Т.С., Полянський С.В., Полянська Т.О., Потапова А.Г. та ін. [1-4; 6,]. 
Економічні науки: збірник наукових праць Луиького національного технічного університету. Серія "Регіональна економіка". Випуск 17 (67). Редкол.: відп. ред. к.е.н., професор І.В. Кривов'язюк. Луиьк: ІВВ Луцького НТУ, 2020. 348 с.

Цілі статті. На основі аналізу структури використання земельних ресурсів вивчити історію досліджень стану земельних ресурсів та особливостей землекористування у Волинській області; проаналізувати вплив фізико-географічні умови на економічну оцінку грунтів, як передумову формування сучасної структури земельного фонду.

Виклад основного матеріалу дослідження 3 повним обгрунтуванням отриманих наукових результатів.

Волинська область розміщена в двох природних зонах у Лісостепу в межах Волинської височини і Поліссі Поліська низовина, а тому має складний i різноманітний грунтовий покрив. Земельна територія області вкрита різноманітною i багатою лісовою, лучною i болотною рослинністю. Деревна рослинність представлена окремими лісами серед орних земель. Луки й пасовища Волинської області складаються з бобових та злакових трав і різнотрав'я. Серед них трапляються костриця, тимофіївка лучна, пирій повзучий, вика та ін.

У Волинському Лісостепу дуже розвинутий мікрорельєф у формі западин і горбкуватих підвищень між ними в умовах високих, еродовоних вододілів. Все це дуже несприятливо позначається на сільськогосподарському виробництві, зумовлює руйнування і зменшення родючості грунтів, тобто сприяє водній ерозії [3]. Характерною рисою рельєфу Полісся $€$ незначна відносна висота i невеликий похил на північ, дуже виражений мезо- і мікрорельєф, що представлений дюнами, грядами, крейдяними горбами 3 невеликими блюдцеподібними зниженнями, дно яких заболочене, а це утруднює механізований обробіток земель. Основними грунтоутворюючими породами є: леси і лесовидні суглинки, морени, воднольодовикові відклади, алювій давній, алювій сучасний, елювій карбонатний порід.

Грунтовий покрив представлений майже всіма грунтами, характерними для лісостепової і поліської природних зон. Основними типами грунтів для області є дерново-підзолисті, опідзолені, чорноземні, дернові та болотні, серед яких 
Економічні науки: збірник наукових праць Луиького національного технічного університету. Серія "Регіональна економіка". Випуск 17 (67). Редкол.: відп. ред. к.е.н., професор І.В. Кривов'язюк. Луиьк: ІВВ Луцького НТУ, 2020. 348 с.

найбільшу площу займають дерново-підзолисті та болотні. За гранулометричним складом грунти займають таку площу: піщані - 63,1 тис. га, звязно-піщані - 1184,3 тис. га, супіщані - 187,1 тис. га, легкосуглинкові - 240,9 тис. га, середньосуглинкові - 7,9 тис. га, що становить відповідно 7,5; 22,$0 ; 22,4 ; 28,8$ і $1,0 \%$ [3].

Перевага в складі земельного фонду Волинської області родючих грунтів, висока густота населення, екстенсивний розвиток продуктивних сил та дія інших чинників зумовили фактично повне залучення земель у господарське використання. Нині лише незначна територія (близько $15 \%$ території регіону) перебуває в природному стані - болота, озера, тощо. Проте, як уже зазначалось, використання земельного фонду має екстенсивний, а тому й нераціональний характер: усі галузі народногосподарського комплексу, які використовують землю, відзначаються надто великою землемісткістю свого виробництва, що в 2-2,6 рази перевищує нормативи в технічно та економічно розвинутих країнах. Із 206 тис. га обстежених кислі грунти становлять 123,5 тис. га, 3 них сильнокислі - 14,3 тис. га, середньо 45,5 тис. га і слабо кислі 63,7 тис. га. В області 1070,0 тис. га заболочених i перезволожених земель, які потребують меліорації. Дефляційно небезпечних грунтів - 225,5 тис. га, в тому числі слабодефльованих - 57,9 тис. га, середньодефльованих - 149,3 тис. га і сильнодефльованих 18,3 тис. га. На території області 95,2 тис. га земель піддається водній ерозії, з яких за ступенем змитості вони поділяються на слабозмиті - 53,8 тис. га, середньозмиті 28,9 тис. га і сильнозмиті - 12,5 тис. га.

Найбільшу площу на території області займають дерново-підзолисті грунти - 324,1 тис. га, або $32,5 \%$ від загальної обстеженої площі. Ясно-сірі та сірі займають площу 74,1 тис. га, темно-сірі і чорноземи - 163,6 тис. га, лучні та дернові грунти - 218,5 тис. га, болотні та торфовища 202,6 тис. га, що відповідно становить 7,4; 16,4; 21,9; 20,8\% $[1 ; 3]$. 
Економічні науки: збірник наукових праць Луиького національного технічного університету. Серія "Регіональна економіка". Випуск 17 (67). Редкол.: відп. ред. к.е.н., професор І.В. Кривов'язюк. Луиьк: ІВВ Луцького НТУ, 2020. 348 с.

Земельний фонд Волинської області загалом має вигідне географічне положення, в центрі Європи. Характерно для земельного фонду регіону його висока освоєність, в результаті чого екологічний стан навколишнього середовища, особливо земельних ресурсів, істотно погіршився і викликає занепокоєння у фахівців. Землезабезпеченість має як економічний, так і екологічний аспект. Використання землі передбачає охорону та розширене відтворення їх родючості. 3 урахуванням особливостей використання земельних ресурсів дослідження має сенс проводити в таких масштабних аспектах: вся земельна територія; сільськогосподарські угіддя; орні землі і т.д.

Аналіз сільськогосподарської освоєності та розораності території області показує, що найнижчий рівень сільськогосподарської освоєності характерний для поліської частини області, де він становить $31,1 \%$ у Шацькому, 32,3 \% - у Маневицькому, 35,0 \% - у Любешівському й 36,4 \% - у КаміньКаширському адміністративних районах. Вищий цей показник у південній частині області - 72,2 $\div 79 \%$. Найвищий рівень сільськогосподарської освоєності у південній частині і становить $79,0 \%$ i 79,5\%. Максимальні показники сільськогосподарської освоєності характерні для Рожищенського $(79,0 \%)$ та Луцького $(79,5 \%)$ районів.

Сільськогосподарські угіддя у земельному фонді області займають 1054,084 тис. га, що становить $53 \%$ від площі всіх земель, 34\% - ліси та лісовкриті площі, 6\% - відкриті заболочені землі, $3 \%$ - забудовані землі, $2 \%$ - землі під водою, $2 \%$ - інші землі.

Актуальною $є$ проблема оптимального визначення перспективних потреб в землі для розміщення продуктивних сил виробництва, предмету та знаряддя праці, засобу виробництва. Землезабезпеченість є істотним чинником в економіці регіону. Різні види земельних ресурсів перебувають у постійній динаміці. За досліджуваний період земельна територія не змінювалась, а отже, звідси можна зробити висновок, що вона відносно стабільна. 
Економічні науки: збірник наукових праць Луиького національного технічного університету. Серія "Регіональна економіка". Випуск 17 (67). Редкол.: відп. ред. к.е.н., професор І.В. Кривов'язюк. Луиьк: ІВВ Луцького НТУ, 2020. 348 с.

Найвища забезпеченість землею спостерігається в таких районах, як Ковельський, Маневицький, Турійський i Шацький (4,0-4,1 га на душу населення), а найнижча - в Іваничівському i Ківерцівському $(1,8-2,1$ га на душу населення). Землезабезпеченість у Волинській області характеризується відносною стабільністю за роками, що потребує детальніших наукових досліджень, оскільки в Україні в цілому спостерігається стала тенденція до зниження забезпеченості земельною територією на душу населення. Випереджаюче зростання густоти населення на одиницю земельної площі порівняно із зростанням сільськогосподарських угідь зумовило зменшення його землезабезпеченості [6].

Розораність земельної території, особливо сільськогосподарських угідь, свідчить про інтенсивність використання земельних ресурсів та продуктивних угідь. Коефіцієнт розораності території - це відношення площі ріллі до площі загального земельного фонду (табл. 1, рис. 1.).

Розораність території досліджуваного регіону знизилася $333,42 \%$ у 2016 р. і до 33,39\% у 2019 р., або на 0,03\%. Площа ріллі дещо скоротилась за досліджуваний період у Волинській області. Звичайно, 3 екологічного боку - це позитивне явище, проте потрібно дослідити детальніше, як відбувається трансформація орних земель, що має вплив на динаміку коефіцієнта розораності території та свідчить про зростання антропогенного навантаження на землю.

Таблиця 1

Розораність земельної території Волинської області, \% [5]

\begin{tabular}{|c|c|c|c|c|c|c|}
\hline \multirow{2}{*}{$\begin{array}{l}\text { Земельні } \\
\text { ресурси }\end{array}$} & \multicolumn{6}{|c|}{ РОКИ } \\
\hline & 2015 & 2016 & 2017 & 2018 & 2019 & $\begin{array}{c} \pm \Delta 2019 \mathrm{p} . \\
\text { до } 2015\end{array}$ \\
\hline $\begin{array}{l}\text { Всього по } \\
\text { області, тис. га }\end{array}$ & 2014,4 & 2014,4 & 2014,4 & 2014,4 & 2014,4 & 0 \\
\hline Рілля, тис. га & 673,2 & 673,2 & 672,6 & 672,6 & 672,6 & $-0,6$ \\
\hline $\begin{array}{l}\text { Коефіцієнт } \\
\text { розораності, \% }\end{array}$ & 33,42 & 33,42 & 33,39 & 33,39 & 33,39 & $-0,03$ \\
\hline
\end{tabular}


Економічні науки: збірник наукових праць Луиького національного технічного університету. Серія "Регіональна економіка". Випуск 17 (67). Редкол.: відп. ред. к.е.н., професор І.В. Кривов’язюк. Луиьк: ІВВ Луцького НТУ, 2020. 348 с.

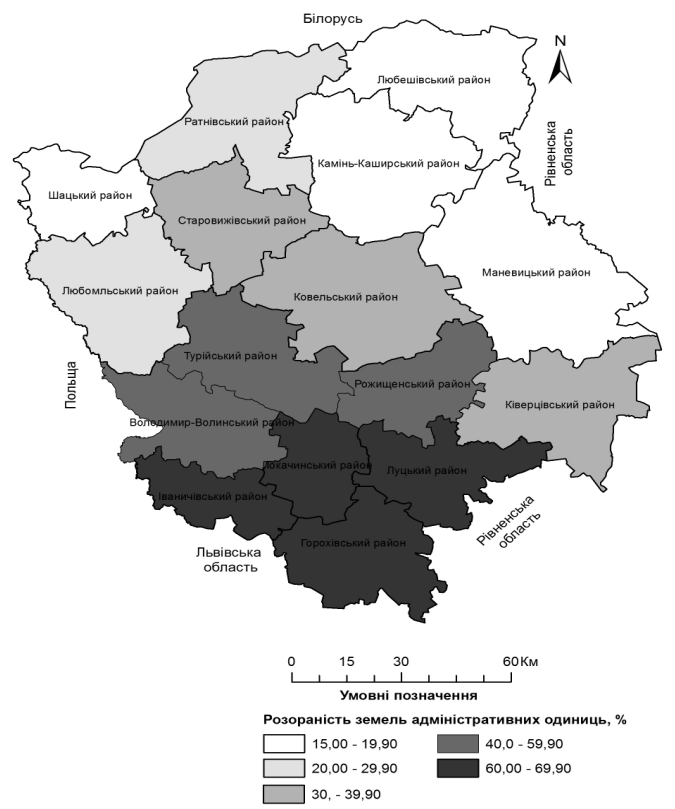

Рис.1. Розораність в розрізі адміністративних одиниць Волинської області [3]

Найбільшу частку в структурі сільськогосподарських угідь займають орні землі - 64,0 \%. Аналізуючи сільськогосподарське використання земель, важливо оцінювати частки й розміщення основних складових частин сільськогосподарських угідь таких, як рілля, багаторічні насадження, сіножаті та пасовища. Орні землі, сіножаті, пасовища та багаторічні насадження входять до складу сільськогосподарських угідь, площі яких у межах області розподілені нерівномірно[7].

Висновки. Доцільно взяти до уваги досвід розвинутих країн у галузі раціонального використання земельних ресурсів: максимальне зменшення забруднення навколишнього середовища, що завдається сільським господарством, промисловим виробництвом, соціально-побутовою діяльністю 
Економічні науки: збірник наукових праць Луиького національного технічного університету. Серія "Регіональна економіка". Випуск 17 (67). Редкол.: відп. ред. к.е.н., професор І.В. Кривов'язюк. Луиьк: ІВВ Луцького НТУ, 2020. 348 с.

та іншими видами господарювання; збільшення доходів селянських господарств шляхом надання субсидій на розвиток виробництва та стимулювання охоронної діяльності за рахунок виплат рентних платежів із інших видів землекористування; розробка та впровадження спеціальних екологічних програм захисту та збереження земельних ресурсів, передбачення джерел фінансування та нагляд за їхнім дотриманням. Для забезпечення сталого розвитку земельних відносин у Волинській області, потрібно виробити чітку стратегію подолання негативних процесів щодо використання та охорони земель. Щоб покращити стан земельних ресурсів, слід провести заходи: вилучення малопродуктивних та непридатних земель iз сільськогосподарського використання; заліснення схилів, ярів, балок; використання нових технологій покращення та відновлення родючості грунтів; використання на підприємствах очисних споруд, які забруднюють навколишнє середовище; відведення земель до категорії природно-заповідного та іншого природоохоронного призначення. У більшості випадків механізми реалізації цих заходів залишаються неефективними, тому що головною проблемою залишається нестача фінансування, також недостатня нормативна база - $є$ проблемою у галузі реалізації земельних відносин.

\section{Список бібліографічного опису}

1. Економічний потенціал Волинської області: монографія / Алла Потапова, Надія Краснопольська. Луцьк : Волиньполіграф, 2016. 174 с.

2. Сучасна структура землекористування Луцького району: агроландшафтний аспект / Т.С. Павловська, О.В. Рудик, В.У. Волошин // Science and Education a New Dimension. Natural and Technical Sciences. 2017. V(14), Issue 132. Budapest, 2017. C. 20-23.

3. Полянський С.В. Грунти Волинської області та рекомендації щодо ï використання / Сучасний екологічний стан та перспективи екологічно безпечного стійкого розвитку Волинської області: кол. моногр. / за ред. В.О. Фесюка. - К.: ТОВ «ПІДПРИСМСТВО «ВІ ЕН ЕЙ», 2016. 316 с.

4. Оцінка ефективності використання i збереження земельних ресурсів Волинської області / Полянський С.В., Князькова Т.О. // Економічні науки. Серія „Економічна теорія та економічна історія”: Збірник наукових праць ЛНТУ. Луцьк : РВВ ЛНТУ, 2011 Вип. 8 (32). С. 292-300.

5. Статистичний щорічник Волинської області за 2019 рік / Управління статистики у Волинській області. Луцьк, 2020. 515 с. 
Економічні науки: збірник наукових праць Луиького національного технічного університету. Серія "Регіональна економіка". Випуск 17 (67). Редкол.: відп. ред. к.е.н., професор І.В. Кривов’язюк. Луцьк: ІВВ Луцького НТУ, 2020. 348 с.

6. Стрішенець О. Стан та перспективи землекористування в Україні: порівняльний аналіз та інтенсифікуючи політика. Економічний часопис Східноєвропейського національного університету імені Лесі Українки : журнал / уклад. Любов Григорівна Ліпич, Мирослава Богданівна Кулинич. Луцьк : Вежа-Друк, 2015. № 4. 85-91 с

7. http://volynska.land.gov.ua/info/zemelnyi-fond-volynskoi-oblasti.

\section{References}

1. Potapova, A. and Krasnopolska, N., (2016), Economic potential of Volyn region, Monograph, Volynpoligraf, Lutsk, p. 174 p.

2. Pavlovskaya T.S., Rudyk O.V. and Voloshin V.V., (2017), Modern structure of land use of Lutsk region: agrolandscape aspect, Science and Education a New Dimension, Natural and Technical Sciences, V (14), Issue 132, Budapest, pp. 20-23.

3. Polyansky S.V. (2016), Soils of the Volyn region and recommendations for their use, Modern ecological state and prospects of ecologically safe sustainable development of the Volyn region: col. monograph / for ed. Fesyuk V.O., K .: LLC "VINE ENTERPRISE", p. 316

4. Polyansky S.V. and Knyazkova T.O., (2016), Estimation of efficiency of use and preservation of land resources of the Volyn region, Economic sciences, Series "Economic Theory and Economic History": Collection of scientific works of LNTU. Lutsk: RVV LNTU, Issue. 8 (32), pp. 292-300.

5. Statistical Yearbook of Volyn region for 2019, (2020), Department of Statistics in Volyn region. Lutsk, p. 515

6. Strishenets O., (2015), Status and prospects of land use in Ukraine: a comparative analysis and intensifying policy, Economic Journal of the East European National University named after Lesya Ukrainka: journal, style. Lyubov Hryhorivna Lipych, Myroslava Bohdanivna Kulinych, Lutsk: Vezha-Druk, № 4, pp. 85-91.

7. http://volynska.land.gov.ua/info/zemelnyi-fond-volynskoi-oblasti. 